SAND94-1984

Distribution

Unlimited Release

Category UC-900

Printed September 1994

\title{
Technology Transfer Information Audit
}

\author{
Mary L. Compton, Kenneth J. Cutshall, \\ and E. David Mays \\ Technical Library Research Department \\ Kathleen A. Manicke \\ Technology Transfer \& Commercialization Center \\ Sandia National Laboratories \\ Albuquerque, New Mexico 87185-0899
}

\begin{abstract}
The Technology Transfer Information Audit was a cooperative effort between the Technology Transfer and Commercialization Center and the Technical Library to evaluate the information services that support Sandia's technology transfer efforts and make recommendations for change. The team's findings include a number of recommendations for improving Technology Transfer and Technical Library services for marketing information, technical information, and document delivery. The report also documents the need for improvements in sharing information on funding sources and internal Sandia information.
\end{abstract}


[THIS PAGE INTENTIONALLY LEFT BLANK.] 


\section{DISCLAIMER}

This report was prepared as an account of work sponsored by an agency of the United States Government. Neither the United States Government nor any agency thereof, nor any of their employees, make any warranty, express or implied, or assumes any legal liability or responsibility for the accuracy, completeness, or usefulness of any information, apparatus, product, or process disclosed, or represents that its use would not infringe privately owned rights. Reference herein to any specific commercial product, process, or service by trade name, trademark, manufacturer, or otherwise does not necessarily constitute or imply its endorsement, recommendation, or favoring by the United States Government or any agency thereof. The views and opinions of authors expressed herein do not necessarily state or reflect those of the United States Government or any agency thereof. 


\section{DISCLAIMER}

Portions of this document may be illegible in electronic image products. Images are produced from the best available original document. 


\section{TABLE OF CONTENTS}

EXECUTIVE SUMMARY ...............................................................................................

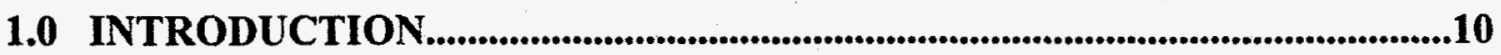

1.1 Project Objectives ........................................................................................ 10

2.0 METHODOLOGY ........................................................................................................11

2.1 Focus Group: Preparations............................................................................11

2.2 Focus Groups: Evaluation Methodology …….........................................12

3.0 MARKETING INFORMATION ...........................................................................14

3.1 The Types of Marketing Information Needed …………..............................15

3.2 Current Services That Provide Marketing Information ................................15

3.3 Marketing Information Needs That Are Not Being Met................................17

3.4 Further Actions That Might Be Taken...........................................................18

4.0 TECHNICAL INFORMATION.................................................................................19

4.1 The Types of Technical Information Needed ...............................................19

4.2 Current Services That Provide Technical Information ...................................19

4.3 Technical Information Needs That Are Not Being Met ...............................20

4.4 Further Actions That Might Be Taken............................................................21

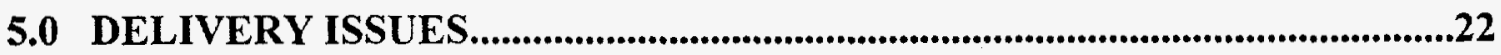

5.1 Types of Access and Delivery Needed .........................................................22

5.2 Current Services in Access and Delivery .....................................................23

5.3 Recommendations for Improvements ...........................................................23

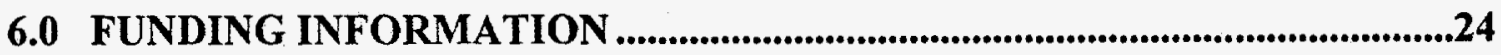

6.1 Types of Funding Information Needed.......................................................24

6.2 Current Services that Meet the Needs............................................................24

6.3 Funding Information Needs Recommendations ..........................................25

7.0 INTERNAL SANDIA INFORMATION …......................................................26

7.1 Types of Internal Sandia Information Needed ................................................26

7.2 Current Services that Meet the Needs.............................................................27

7.3 Internal Information Needs That Are Not Being Met...................................27

7.4 Further Actions That Might Be Taken.........................................................28 


\subsection{OTHER INFORMATION}

8.1 The Parking Lot Information Needs .........................................................29

8.2 Current Activities that Meet The Parking Lot Needs ..................................30

8.3 When the Parking Lot is full of Parked Information Needs ..........................30

8.4 Further Actions That Might Be Taken..........................................................31

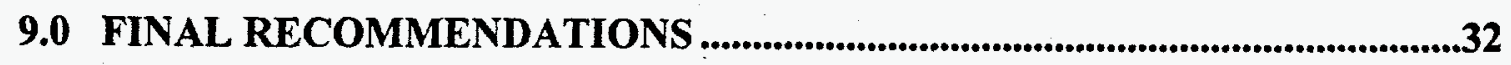

9.1 Marketing Information - Recommendations..............................................32

9.2 Technical Information - Recommendations.................................................32

9.3 Delivery Issues - Recommendations........................................................33

9.4 Funding and Internal Information - Recommendations.................................33

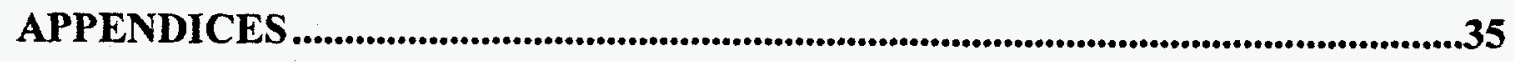

APPENDIX A: PROJECT CHARTER ……................................................

APPENDIX B: LIST OF FOCUS GROUP PARTICIPANTS AND

LETTERS TO PARTICIPANTS ...............................................................39

APPENDIX C: SPECIFIC FOCUS GROUP RESPONSES ………....................43

APPENDIX D: BODY LANGUAGE NOTES ……….............................59

APPENDIX E: SOURCES OFTEN USED FOR MARKETING

APPENDIX F: FLOW CHART OF MARKETING SERVICES AND

MENU OF AVAILABLE PRODUCTS

APPENDIX G: TYPES OF MARKETING STUDIES PROVIDED 


\section{EXECUTIVE SUMMARY}

The Technology Transfer Information Audit project team was formed in April 1994 as a cooperative effort between the Technology Transfer Program Support Department, 4202 and the Technical Library Information Research Department, 13415 to evaluate existing information services that support Sandia Technology Transfer efforts and to recommend improvements, new products and services.

\section{Summary of the Methodology}

The team decided that direct customer interaction in the form of focus groups would be the best method to gather customer requirements and expectations quickly. The team then compared information needs to current services, identified unmet information needs, made recommendations for improvements in current services and for new services, and prioritized these changes for implementation.

\section{Summary of the Findings}

Following the focus groups, information needs were grouped into 6 broad categories: Marketing Information, Technical Information, Delivery Issues, Funding Information, Internal Sandia Information, and Other Information. These categories are listed in order of importance to the focus group participants. The majority of response fell in the first three categories and therefore are the major emphases of the team's recommendations. The need for marketing information, including information about companies, industries, regulations, marketing segments, products, etc., topped the list of information needs expressed by participants. This was followed by the need for technical information in the form of articles, reports, patents, etc. Delivery of the information, both the delivery mechanisms and turnaround time was third in priority.

\section{Summary of the Recommendations}

Marketing Information: Since the marketing information needs were the most extensive and of the highest priority for the members of the focus groups, most of the recommendations concern marketing information needs:

Design a Marketing Education Strategy - Both the Technical Library and Technology Transfer should combine resources and expertise to design a marketing seminar. 
Communicate the Marketing Services - Create a campaign designed to emphasize the importance of Marketing at Sandia.

Work Together to Define a Smooth Process - Build on a good thing. Develop clear processes for internal market research and publicize it.

Build the library's collection of resources that supports technology transfer activities Select, purchase and make available journals, books, reports, and databases in tandem with Technology Transfer. Purchase of some of some new databases on CD-ROM is currently underway.

Assign a Technical Information Specialist to be a marketing information specialist The Technical Library decided to designate one Technical Information Specialist as a marketing information specialist in July 1994. Implementation of this plan is in progress.

Technical Information: The Technical Library and the Technical Information Specialists do a good job of providing technical information. There is a lack of awareness about the current products and services that the Technical Library offers. The approach used for marketing information applies equally to the technical information. Therefore, the working group recommendations for technical information include:

Design a Technical Information Education Strategy - The Technical Library has extensive resources and skills in the area of technical data. Many new products and services have, or are being reviewed and added to the Technical Library's menu.

Educational workshops, classes, or seminars should be created to raise awareness and educate technical staff on the value of these products and services.

Communicate the Technical Information Services - Promotional activities such as wide announcement of the training workshops, articles in internal publications, a promotional brochure or one page flyer, etc. should be developed.

Build the library's collection of databases - Select, purchase, and make available databases that index the technical literature that will enable customers to do some of their own searching. Purchasing of several CD-ROM products that index the technical literature is also underway now.

Delivery Issues: The wants of information users in this area far outstrip the available resources and currently available communications technology at Sandia. As fiber optics come to every building, the transition to a "paperless" environment will gradually follow. Libraries nationwide will move towards electronic storage and retrieval of information, and use of print material will decrease. In the interim, low technology solutions can be applied. For instance, a Technical Library staff member has been assigned to facilitate and improve the delivery process. This is a start at making improvements. 
Funding and Internal Sandia Information: The funding information that is needed and the internal Sandia information that was desired are complex issues outside the scope of this project. However, the working group recommendations for providing funding information and internal Sandia information are:

Locate an owner of Funding Information - Currently, Technology Transfer is tracking some of the Federally funded programs. Could a funding working group be brought together across organizations with output from the group published on a regular basis? Communicate Internal Information Needs to Architecture Project - The owner of this issue is outside of the focus of Technology Transfer or the Technical Library, although both organizations can certainly contribute information to this network once it is developed and implemented. A possible service that would meet this information need is a Sandia "yellow pages" of products and services offered by various department at the Laboratories.

\section{Recent Development}

In August 1994 Carol Sumpter, Intellectual Property Development Department, 11510, covened the first meeting of the Market Research Working Group. Two members of the Technology Transfer Information Audit project team are members of this group. Some of the recommendations mentioned in this document may be referred to the Market Research Working Group for implementation. 


\subsection{INTRODUCTION}

The Technology Transfer Information Audit (TTIA) project team was formed in April 1994 as a cooperative effort between the Technology Transfer Program Support Department, 4202 and the Technical Library Information Research Department, 13415 to evaluate existing information services that support Sandia Technology Transfer efforts and to recommend improvements, new products and services. The project charter is included as Appendix A.

Technology transfer is an important new mission for Sandia National Laboratories, and the provision of business and marketing information is a relatively new role for the Technical Library. The results of this audit will be used by the Technical Library and the Technology Transfer \& Commercialization Center to meet the information needs of Sandia National Laboratories in the most cost-effective manner.

The members of the project team were Mary L. Compton, Kenneth J. Cutshall, E. David Mays, all 13415 and Kathleen A. Manicke, 4202.

\subsection{Project Objectives}

To achieve its goal, the project team completed the following tasks:

- identified technology transfer information customers

- selected the methods to be used to gather and evaluate customer input

- gathered customer information requirements and expectations

- evaluated customer input and compared it to existing systems to reveal gaps in information needs

- identified improvements for existing services and new services

- made recommendations for implementing changes in services

- issued a report of its findings

For some of the team's recommendations, management will have to resolve funding issues. This report summarizes the project team's findings. 


\subsection{METHODOLOGY}

This section reviews the methods used by the project team to gather and evaluate customer input. The team decided that direct customer interaction in the form of focus groups would be the best method to gather customer requirements and expectations quickly. According to Philip Kotler ${ }^{1}$ in his classic book Marketing Management, focus group research, "is a useful exploratory step... It provides insight into consumer perceptions, attitudes, and satisfaction that will be important..." A focus group is usually a gathering of 6-10 persons who spend a few hours with a skilled interviewer to discuss a project, service, organization. The focus group meetings are informal, and refreshments are usually served. Consumer product manufacturers use this technique frequently; service organizations are increasingly using this technique too.

Following the focus groups, information needs were grouped into 6 categories. The team then compared information needs to current services, identified unmet information needs, made recommendations for improvements in current services and for new services, and prioritized these changes for implementation.

\subsection{Focus Group: Preparations}

The team consulted Jeanne Evans, Quality Tools, 12911, for advice on how to gather data using focus groups. The team also consulted Heather Allen, Statistics and Human Factors, 12323, for advice on how to select customers for the focus groups. The team then compiled a list of customers who had used Technical Library and Technology Transfer services in the past. This list included both technical staff and technology transfer staff. The team selected twenty customers from the list to participate in two focus groups. Team members contacted the selected customers to invite them to participate. A confirmation letter that included details about the meetings was subsequently sent to each participant. (See Appendix B for participants list and letters to participants).

The team outlined of the types of information it hoped to gain from the focus groups. The team located a facilitator, Ruth Duggan, who had completed the facilitation skills class, for the focus group meetings. The team and the facilitator met to finalize plans for the focus groups. Three team members were assigned to serve as recorders, attempting to document participants responses verbatim. Another member's role was to observe participants body language during the meetings. As part of her role as facilitator, Ruth Duggan recorded the important points of participants responses on flip charts.

${ }^{1}$ Kotler, Philip. Marketing Management: Analysis, Planning, Implementation, and Control. Englewood Cliffs, N. J.: Prentice-Hall, Inc., 1988. 
The agenda for the meetings was:

- Ground rules

- Current Information Gathering Techniques

- Other Information Needs

- Why These Other Information Needs Are Not Accessible

- Essential Needs Assessment

- Summary and Wrap-up.

Each agenda item was assigned a time limit to assure that the needed information would be obtained within the two hours allotted for each meeting. The focus group meetings were held June 7th and 8th in the conference room in the Technology Transfer Building in Research Park. Although each focus group deviated from the agenda, sufficient data was gathered so that the team could adequately assess what information resources are needed to support Sandia's technology transfer efforts.

Nineteen out of the twenty participants wanted to receive a copy of the team's findings.

\subsection{Focus Groups: Evaluation Methodology}

Using the flip charts and notes recorded during the meetings the team sorted the information needs into broad categories:

- Marketing Information

- Technical Information

- Delivery Issues

- Funding Information

- Internal Sandia Information

- Other Information

Appendix $\mathrm{C}$ contains copies of the flips charts recorded during the focus group meetings. The flip charts and the recorders' notes provided the data from which the team identified the major types of unmet information needs and recognized that most of these needs fell into one broad category.

These categories are listed in order of importance to the focus group participants. The majority of response fell in the first three categories and therefore are the major emphases of the team's recommendations. The need for marketing information, including information about companies, industries, regulations, marketing segments, products, etc., topped the list of information needs expressed by participants. This was followed by the need for technical information in the form of articles, reports, patents, etc. Delivery of the information, both the delivery mechanisms and turnaround time was third in priority. 
Detailed discussions of the information needs, including current services meeting those needs, recommendations for changes in services, and recommendation for further study can be found in the next six sections of this report. Specific focus group responses (the raw data ), are listed in Appendix C. A list of the recorded gestures, facial expressions, and body postures observed during the focus groups, can be found in Appendix D. 


\subsection{MARKETING INFORMATION}

One of the stated new missions of the national laboratories is technology transfer. For the purposes of this report technology transfer is defined as the exchange technologies which were created for one purpose to a different situation, for a different purpose.

The United States Congress has passed several pieces of legislation in the last 15 years concerning technology transfer activities within government agencies. The StevensonWydler Technology Innovation Act of 1980 was passed, in part, to establish a technology transfer mission for federal agencies and their research and development laboratories. This act also established offices of research and technology applications within government laboratories and set aside funds for technology transfer in agencies' research and development budgets. ${ }^{2}$ The Federal Technology Transfer Act of 1986 authorized government-owned, government-operated laboratories to enter into cooperative research agreements with state and local governments, universities, and private companies. ${ }^{3,4}$ The National Competitiveness Technology Transfer Act of 1989 (NCTTA), part of the National Defense Authorization Act for FY90-FY91, authorized government-owned, contractor-operated laboratories, like Sandia, to participate in cooperative research and development agreements (CRADAs) with nonfederal entities to facilitate technology transfer to the private sector. ${ }^{5}$ The National Defense Authorization Act for FY93 facilitates technology transfer to small businesses by requiring the Department of Energy (DOE) to expedite review of CRADAs between laboratories and small businesses. ${ }^{6}$ Passage of the NCTTA has made technology transfer one the five major mission assignments for Sandia.?

To complete this mission, Sandia must understand the needs of American industry. Entities in both the public and private sectors may have different needs. The key to technology transfer is information; specifically market-driven information.

This section will examine what types of information are perceived to be needed. It will compare these types of information with current services, within Sandia's Technical Library, and the Office of Technology Transfer \& Commercialization, that are available to meet these needs. Unmet information needs, resulting in dissatisfaction, and what actions are required to create satisfaction will also be discussed.

\footnotetext{
${ }^{2}$ Public Law 96-480, approved October 21, 1980.

3Public Law 99-502, approved October 20, 1986.

${ }^{4}$ Wisler, Carl E. Implementation of the Technology Transfer Act: A Preliminary Assessment. Washington, D.C.: United States General Accounting Office, 1990.

${ }^{5}$ Public Law 101-189, approved November 29, 1989, Title XXXI, Part C. 6Public Law 102-484, approved October 23, 1992, Title XXXI.

${ }^{7}$ Sandia National Laboratories. Institutional Plan, FY1994-1999. Albuquerque, N.M., Livermore, Ca.: Sandia National Laboratories, 1993. (SAND93-2069)
} 


\subsection{The Types of Marketing Information Needed}

Several types of marketing information were identified from the meetings of the two focus groups. These informational categories include:

Company Information - Annual reports, reports required by the Securities and Exchange Commission, identification of decision makers, organizational charts, sales and market share information, profitability, licensing information, and R\&D base. Lists of potential partners including executive names, addresses, and phone numbers.

Industry Information - Standard Industrial Classification (SIC) code identification, total industry size, total industry sales, structure of the industry including major companies, trade associations, and distribution channels, common promotional methods, profit margins, capital expenditures, royalties, history of the industry, forecasted growth, value of shipments, number of employees, value added, and balance of payments.

External Environment - Relevant legal, political, environmental, demographic, regulatory, and technological factors which impact a given industry and technology.

Market Segment - Much of the same information listed under the industry heading, except for each of the potential applications for the technology.

Product Concept - Product-level information on: total sales for the product, company market share for the product, product life cycle, stage of development, future need levels, end-users, barriers to entry, SWOT (strength, weakness, opportunity, threat) analysis, competitive analysis, pricing criteria, originality of idea/patent search current state-of-theart.

\subsection{Current Services That Provide Marketing Information}

Although it appears that there is a huge unmet demand for marketing information, much of the needed information can be located using existing services at Sandia.

\section{Technical Library Services}

The Technical Library has a wealth of information available, mainly online through Dialog Information Services, Inc., a search system that provides access to over 400 commercial databases. Appendix E, "Sources Often Used for Marketing Information," summarizes just a few of these sources. The online service is operated on a cost recovery basis, with line organizations picking up the costs of the search fees. The Technical Information Specialists at the Technical Library have extensive training in the use of both print and online research methods. They can answer specific questions relating to the market, or collect information from a wide variety of sources to create a overall picture of the industry. Because the information specialist work with the online 
sources day-in and day-out, they are a more cost effective avenue for gaining the marketing information of interest.

The Technical Information Specialists build the library's collection to meet all of Sandia's corporate information needs. When the information is not readily available from within Sandia's resources, the technical library may utilize outside private market research firm reports, or other business-oriented libraries such as University of New Mexico's Parish Library.

Still some of the information will not be available due to the proprietary nature of the information, or a lack of research that has been done on that topic.

\section{Technology Transfer Services}

The Office of Technology Transfer \& Commercialization has a marketing support function housed within it. These services are in the areas of promotions and market research. Contained in Appendix $\mathrm{F}$ is a process flow chart of the marketing services, as well as a menu of available products. The promotions area operates on a direct productcost recovery basis. The research function operates in a similar method.

The market research function is mainly limited to analysis and report writing. Based on an initial interview of the clients needs, and a literature search of marketing information gathered by the Technical Library, the market researcher then attempts to put together a picture of the market factors. Some additional research may be warranted depending upon the nature of the project. Outside secondary and primary research is also conducted on a limited basis. See Appendix $G$ for a complete listing of the types of studies that this support function provides.

In addition, the Intellectual Property (IP) Development Office conducts market research for newly developed technologies that have filed a technical advance. A patent search, and an external environmental scan of existing business and technical factors are reviewed. The marketing information is summarized into a one-page, high-level overview of the market for the technology, and scored according to its market potential before a patent is even pursued. 


\subsection{Marketing Information Needs That Are Not Being Met}

In the majority of cases, the information requested by the focus groups is available currently. The dissatisfaction expressed, therefore resulted more from the information delivery scheme, and from the lack of knowledge of what is available. These disconnects included:

- Lack of user-friendly, end-user driven, widely distributed at the individual PC level information

- Lack of quick response mechanisms for service providers

- Slow overall turn around times

- Unclear division of marketing related services throughout the lab

- Lack of financial and human resource support for marketing information

- Lack of education on the importance of marketing-the "whys" and the "how-to's"

Below are listed actions that could help correct some of the problems that have been identified.

Educate - Host training sessions sponsored by both the Technical Library and Technology Transfer. Advertise the services of both organizations in the Lab News. Have announcements in the Weekly Bulletin. Create a Marketing Information Speakers Bureau within Sandia. Showcase and display case-studies in the library and/or Technology Transfer. Develop a seminar which would include working sessions for interested Sandia personnel. Add notices in the Tech Transfer Update. Set up a home page for Technology Transfer and Technical Library services on Mosaic.

Investigate - Perform a cost-benefit analysis of selected external marketing products/services (e.g. TechMonitoring, Value-Line, CD-ROM's, Compact Disclosure.) Try to determine the cost of bringing information to people's desktop. The Technical Library is actively researching and purchasing CD-ROM products such as: CASSIS (a patent product), the National Trade Data Bank, Statistical Abstract, F\&S Index Plus Text. Eventually these products will be accessible at the individual PC level. In library work stations will be used in the interim. 
Coordinate - With the Architecture Project in Integrated Information Services, 13205, for networking issues. Discover how much of the needed information is available on Internet, how Sandia can access it, and how to inform people of this resource. To increase visibility, set-up a home page on Mosaic for the Technical Library and Technology Transfer.

Reorganize - Calculate how many market research reports are needed lab-wide, without regard for cost or human resources. Justify an approach to met this demand. Many questions need to be answered: Do we need more end-user searching capabilities? Do we need several information specialists who focus on marketing data? Is the Technology Transfer office the right home for marketing research writing services? Should a market research department be created and staffed to meet this demand, or should this be handled by an outside contract?

Partner - Exchange personnel between Technology Transfer and Technical Library for a short term fix. An information specialist could sit over at Technology Transfer 1 day per week to answer quick questions via an online workstation. A market research specialist from Technology Transfer could come to the Technical Library 1 day per week to assist in marketing information research design, analysis, and report writing on topics with a marketing/technology transfer bent. (The Technical Library has already designated one staff member as the marketing information specialist.)

\subsection{Further Actions That Might Be Taken}

Given the numerous ideas listed above, there seems to be many steps that could be taken to move towards the creation of satisfied customers. These recommendations can be organized into short-term and long-term solutions. Overall the following actions will be needed in order to ensure that the valuable information gained through focus group research, will not be lost.

- Continue to document demand level for market research

- Circulate "marketing needs" white paper to get top management support

- Select activities from the 5-step action points

- Plan for short-term fixes such as the educational component of the recommendation section, and execute

- Perform additional needs definition exercises (e.g. telephone interviews; mailed surveys; new, issue-focused working groups) to determine long-term strategies 


\subsection{TECHNICAL INFORMATION}

Sandia can participate in technology transfer because it generates technical information that can be transferred. Part of the process of performing research on a particular topic is to become familiar with the existing information on that topic. The provision of technical information to Sandians has always been the primary mission of the Technical Library.

\subsection{The Types of Technical Information Needed}

Technical information can be found in a variety of sources. Information published in journal articles or conference proceedings can usually be easily identified and obtained. Technical reports often contain useful information. However those produced by government agencies, that are classified, or those generated by private-sector companies are often very difficult to identify and to obtain. Patents, too, contain a wealth of information. And finally, one should not ignore technical information produced overseas.

Members of the focus groups discussed all of these various types of technical information. Nevertheless the specifically stated information needs included:

- Patent searches

- Foreign scientific journals/articles

- Up to the minute technology trend tracking

Researchers can drown in the available information, help is needed sometimes in sorting through the results of literature searches that are performed. This is where end-user searching, and assistance from a market researcher could be beneficial.

\subsection{Current Services That Provide Technical Information}

\section{Technical Library Services}

The following products and services are available from the Technical Library as sources of technical information:

- Technical Information Specialists, who, on a cost recovery basis, will perform literature searches for customers

- Major indexing and abstracting publications so that anyone can perform a manual search

- Passwords for commercial online search services so that customers can perform their own online literature searches (A maintenance fee is charged for this service) 
- Current awareness service that provide lists of recently published papers and reports on a given subject

- Current awareness publications that announce new books, journals and reports acquired by the library

- Document delivery service so that customers can obtain copies needed articles and reports (Section 6.0 deals with document delivery in greater detail.)

- Translation service for non-English materials

The Technical Library is also a member of the Library Services Alliance, an agreement between six science and technology libraries in New Mexico to share resources when possible. The Alliance members are the libraries at: Sandia National Laboratories, Los Alamos National Laboratory, Phillips Laboratory, University of New Mexico (Centennial Library), New Mexico Institute of Mining and Technology, and New Mexico State University. The Alliance is currently developing ways to share resources among member libraries.

\subsection{Technical Information Needs That Are Not Being Met}

It was apparent from comments heard during the focus group meetings that the Technical Library needs to do a better job of educating current and potential customers about its existing services. Many Sandians would like to perform their own "quick and dirty" searches. However, few of these Sandians are interested in using the existing printed indexes. In particular, interest was expressed in a product that would provide better access to the patent literature and in having access to these products at the individual PC level. Several participants also expressed frustration in staying current with the literature.

Some ideas for improvement, that address the dissatisfaction mentioned in the previous paragraph include:

Educate - Better educate current and potential customers about existing services, especially its current awareness services. Co-host training sessions with Technology Transfer. Advertise services in the Lab News. Announce new and changes in services in the Weekly Bulletin. 
Investigate - Provide other alternatives for Sandians to perform their own "quick and dirty" online searches, especially for the patent literature. The Technical Library is currently researching and purchasing several CD-ROM products that provide bibliographic access to the technical literature, such as: CASSIS (patent literature), INSPEC (physics, electronics, and computer science literature), Ei - Compendex Plus (engineering literature), Aerospace Database, Energy Science and Technology. As mentioned in section 3.3 these products sill eventually be accessible at the individual PC level, with in library access offered in the interim. Offer other alternatives for current awareness. The Technical Library is currently implementing an online table of contents service for its customers that is more current than the products and services mentioned above.

\subsection{Further Actions That Might Be Taken}

Satisfying the unmet technical information needs requires some changes by the Technical Library. These changes mostly involve educating our customers as to our capabilities and providing easier access to products that index the technical literature. Recommendations include:

- Implement the activities from the action points above

- Plan for the educational component of the recommendation section and execute 


\subsection{DELIVERY ISSUES}

During the process of determining the customers information needs, statements were made that indicate some customers are unaware of what information is readily available and what information is actually accessible. The purpose of this section is to identify the needs and expectations of the customer in the area of information access and delivery.

\subsection{Types of Access and Delivery Needed}

The following headings are sub-topics revealed by the focus groups as needs in the access and delivery area, including:

One-Stop Shopping - Who does what? A publication "yellow pages" needs to be created and maintained for Technology Transfer/Technical Library regarding the services available and contact numbers of residence experts on various technologies at Sandia.

List of Existing Resources - The library should put together an annotated list of not just the names of existing information resources, but also a list of the information located in each resource. This would aid the library customers who wish to find information on their own, thus encouraging end-user searching.

Internet User Aids - With the growth of the Internet and the information sources on it, a need for some navigation tools and user guides are essential to help the customer to find relevant information.

Desktop Electronic Easy Access - An interface between the user and information resources is desired at desktop level. It needs to be transparent because customers do not want to learn multiple systems.

Foreign Information - Documents in languages other than English need to be delivered in a timely fashion, including translations if desired.

Baseline Service with Grades - "Packages" of information should be defined to aid the customer in making decisions regarding cost and amount of information required. It would be desirable to have a basic "no-cost-package" for those organizations lacking sufficient funding.

Information processed and filtered into summarized final product - Users indicated that it would be desirable to have some of the information processed into an executive summary, or brief report. 


\subsection{Current Services in Access and Delivery}

Some of the needs for access and delivery covered above are actually being met with current services. The Technical Information Specialists have access to many full text marketing and business databases which enables them to provide current information immediately.

- The University of New Mexico currently provides services for interlibrary loan and document delivery. The Technical Library has implemented some rapid document delivery strategies such as Ariel and Dialog Patent Service. The library also plans to make a Technical Information Specialist responsible for improving document delivery and access services.

- Intellectual Property provides services for summarizing of information into executive summaries related to Sandia technical disclosures.

- Technology Transfer has market research report writing services available on a limited basis.

- Sandia has a World Wide Web server which contains a significant amount of information on technologies available and contact numbers.

- Technology Transfer offers brochures about technologies and educational classes on intellectual property, market research, and licensing.

\subsection{Recommendations for Improvements}

Reorganize - Improve the document delivery and interlibrary loan processes to better track document requests and decrease turnaround time for filling document requests. Implement the Technical Library's plan to have one Technical Information Specialist responsible for improving document delivery services.

Develop - Compile an annotated list of information resources relevant to technology transfer. Write Internet navigation tools and user guides that will assist customers in finding relevant information on the Internet.

Partner - Exchange personnel between Technology Transfer and Technical Library. As mentioned in section 3.3 an information specialist could sit over at Technology Transfer one day per week. A market research specialist could come to the Technical Library one day per week to assist with marketing information research design, analysis, and report writing. 


\subsection{FUNDING INFORMATION}

Focus group participants indicated that information about funding sources for projects is an umet information need. Without the necessary funding many potential technology transfer projects never get off the ground. Assistance is needed not only in finding potential funding sources, but also in keeping this information current.

\subsection{Types of Funding Information Needed}

Focus group participants expressed the need for two types of funding information. The first is information on funding sources for projects and information on federal projects in progress. Finding information on funding sources, both internal and external to Sandia, is difficult. This information changes rapidly and must be current to be useful. A mechanism to obtain, filter, and coordinate the information is also desired.

The second type of information need is for idea development or "seed" money. Scientists and engineers often need time to develop an idea to determine if it is feasible before a project can be proposed for funding. Both staff time and literature searches are included in these costs. Technical staff's time must be often be charged to funded project and no budget exists for exploring new ideas. The LDRD (Laboratory Directed Research/Development) program will have some money available for idea development next year.

\subsection{Current Services that Meet the Needs}

Commerce Business Daily (CBD) - online and in paper form are both available through the Technical Library and on New Mexico Technet.

Broad Agency Announcements (BAA's) - online through the Technical Library and on New Mexico Technet.

Fed World - online via the Internet.

Direct Contact - other government agencies have funding programs available. Usually there is also a program office that handles inquires into funding source location. Directories of these agencies are available in the Technical Library. 


\subsection{Funding Information Needs Recommendations}

Some of the information requested by the focus groups is currently available, but its accessibility may be limited and there may be a lack of knowledge on what is available. Recommendations include:

- Make the sources listed in above easily accessible throughout the Laboratories.

- Advertise the type of information these products contain and their availability to customers.

- Create or purchase other online and print products that contain the needed information and make them easily available to customers, preferably at the individual PC level.

- Extend Technology Transfer's role as a gathering, filtering and coordinating organization for this type of funding information. This is already being done for the Small Business Innovative Research/Small Business Technology Transfer program, Advanced Technology Program, and Technology Transfer Initiative funding program. 


\subsection{INTERNAL SANDIA INFORMATION}

During our focus groups customers also expressed the need for better access to internal (Sandia) information. Sharing information within Sandia is often difficult and cumbersome. A major part of the problem is knowing where to go to get needed information.

\subsection{Types of Internal Sandia Information Needed}

Categories of internal Sandia information mentioned by focus group participants included:

Information about trade shows and conferences - two types of information are needed:

- Database or electronic bulletin board that lists information about upcoming conferences, meetings and trade shows (performing a similar function to that of conference announcements bulletin board in the Technical Library.)

- Database or electronic bulletin board that indicates what conferences, meetings and trade shows that Sandians (groups or individuals) will participate or have participated in.

Internal Sandia databases - Make several internal Sandia databases more widely available within the laboratories. Privacy and security issues will need to be addressed in order to make these databases more widely available even within Sandia. Databases should have a common user interface and a standard format. Examples are:

- Intellectual Property Database owned by Carol Sumpter

- Employee Skills Database currently under development by Human Resources

- CRADA Database owned by Technology Transfer

- McGraw-Hill Link Labs managed by John Cummings (This database may be out-ofdate.)

- Database of Sandia Laboratories Facilities managed by Jerry Hanks

Directory of Sandia Laboratories Internal Services - Create a "yellow pages" type of directory and guide to the various services (Technology Transfer, Technical Library, etc.) available within the Laboratories. Should be issued separately from the telephone book and updated frequently, or better yet be online with real time updates. Entries should include what the service is, who to contact and basic rates. Brochures are not updated frequently enough to meet customer needs, and they hard to keep track of. This online directory could appear as part of a "home page" on Mosaic.

Centralized project information - Centralize information about Sandia and other government projects to either avoid duplication or promote synergism of efforts. Internal 
communication about projects within Sandia is not effective.

Customer/Company/Industry contact information - Accumulate information about company or industry visitors and customer points of contact into a database. The database should be searchable by area of expertise, as well as by company and individual and offer Boolean search capabilities. The CRADA database does this for companies with which Sandia has signed CRADAs. The Protocol Office has this information for corporate level visitors. Personnel Security/Visitor Control also has information on Sandia visitors, but this information may be co-mingled with security information.

Database of display materials - Gather materials available, such as photographs, charts, brochures etc., for use in displays both locally and at conference and trade shows.

Brief articles in technical newsletters - Provide online bibliographic or full text access to these articles which often supply citations to articles and reports that discuss the same technology in greater detail and/or names of contacts for more information.

\subsection{Current Services that Meet the Needs}

In most cases the above information needs are not being met. Reasons for this are:

- Needed internal information exists and is in a database, but the database is not widely available to Sandians.

- Needed internal information exists, but has not been brought together in a common database or publication.

However, in the area of trade show information at least two databases containing information on conferences, trade shows, and meetings past and forthcoming are available. These commercial databases can be searched by subject keyword, sponsoring organization, conference location and conference title. Technical Information Specialists in the Technical Library or end-user can search these databases if they have the necessary passwords. The Technical Library also purchase printed products that are guides to these events.

Regarding brief articles in Sandia technical newsletters, each issue of a technical newsletter received by the Technical Library has a separate record in the Technical Library's unclassified database.

\subsection{Internal Information Needs That Are Not Being Met}

As mentioned above most of the information needs mentioned in this section are not being met, or at least the needed information is not in a form that is widely available to 
Sandians. Again, as stated in section 3.3, there is a general lack of user-friendly; end-user driven; widely distributed PC level information available at Sandia.

There are some recommendations for meeting some of the needs expressed above:

Investigate - Create or purchase a product that would serve as an online or published alerting service for upcoming trade shows, conferences, and meetings, perhaps by utilizing the two databases mentioned above to create a product that would meet Sandia's specific needs.

Investigate - Move the information about where a conference paper is to be presented to a searchable field in the Technical Library's unclassified online catalog. This information is currently captured in an unsearchable note for each conference paper and abstract that goes through the review and approval process. The library is currently installing new software to run this database. The implementation team is investigating searchable fields available in the new software for this data.

Advertise - Publicize these new products or capabilities as they become available to customers.

Coordinate - Work with the Architecture Project to make existing internal databases more widely available to Sandians and to create databases that would satisfy other internal information needs mentioned above. These databases should have a common user interface and a standard format.

Investigate - Make full text of the Sandia technical newsletters available via the Technical Library's unclassified online catalog. The Technical Library is currently investigating imaging systems that could be used to digitize internal unclassified unlimited reports. Most of the Sandia technical newsletters fall into this category of Sandia publications and therefore would be included in this initial group of digitized reports.

\subsection{Further Actions That Might Be Taken}

- Perform additional needs definition exercises (for example telephone interviews, written surveys, etc.) to determine priorities for meeting internal information needs.

- Plan the short term fixes mentioned above and complete the long term investigations currently underway. 


\subsection{OTHER INFORMATION}

Focus group members, at times, would bring up issues that were not directly related to the topic under investigation. However, the facilitator and the TTIA working group members thought these comments still represented information needs. These "parking lot" issues do not appear to be directly applicable to the Technical Library nor the Technology Transfer office function. Therefore most of the needs in the parking lot category are beyond the control of this group, and somewhat out of the scope of the stakeholders' domains too. However, a summary of this information is included in the report for consistency of the sections.

\subsection{The Parking Lot Information Needs}

According to statements made during the focus groups, categories of information needs kept popping-up. These issue fell into two broad categories- functions $\&$ funding.

Functions - Educate and communicate throughout the laboratory on the division of labor, areas of specialization; to avoid duplication of efforts. For instance adopt crossfunctional teams, both for internal operations-oriented projects, and for external Technology Transfer-oriented projects. The Sandia Employee Resource Profile database, currently under development in the Laboratory Development Division, will meet this need.

Included in this notion, was the suggestion for VP-level evaluation across divisions to develop a common set of information (market analysis related), and a common language to discuss marketing/business information needs. This can really only be achieved by the education and training of line organizations in marketing and market research techniques. The Marketing Information section of this paper, recommends a training component as a part of the action plan. This recommendation is further supported by the focus groups' stated overall need to know "who does what."

Funding - Allocate "seed" money for technology transfer activities. Business development activities such as creation of promotional materials for technologies, travel, conference and trade show attendance, proposal writing, alternative funding (seek \& select), patent development, technology maturation-all require money which now has to come out of general overhead. In addition, the employee evaluation review does not credit technology transfer activities. There is no incentive to develop technologies into business-wise, market-driven products.

The issue of who pays for marketing information was also raised. Should it be a total charge back system? Should Technology Transfer, just as the Technical Library, operate under the Service Center concept? 
The need to know DOE's funding plans in advance was also expressed. Included in this area is the need for an overall funding matrix of other agency source of R\&D moneys, and how to go after these funding sources.

\subsection{Current Activities that Meet The Parking Lot Needs}

As mentioned above the Laboratory Development Division is conducting a Sandia Employee Resource Profile for all of its division. Carol Sumpter in the Intellectual Property Development Department wrote a white paper on marketing functions throughout the Laboratory, and is developing a market research working group. Some Technology Transfer activities are focusing on cross organizational interactions. Evidence for this lies in the creation of application oriented technology areas that are managed by Technology Transfer Product Area Managers (PAMs). One example is the biomedical area which includes technologies that range from information technology to sensors. The creation of an automotive-focused PAM, who's technologies encompassed materials, advanced manufacturing, computing, is also an indication.

In the funding area there is a new policy (in review) which will allow royalty sharing according to an equitable distribution scheme. These moneys could be made available at the discretion of the line organizations to use for business development activities if desired.

The Service Center issue, or "who pays for what" is pretty well defined in the Technical Library already. The Technical Library does operate on a cost recovery basis. Presently, Technology Transfer does not have a consistent internal policy on charge back.

Technology Transfer covers some of the Transfer services such as CRADA processing, coordination of industry visits, and internal market research reports. Other technology transfer services are paid for by the line, such as the marketing promotions support services. A management decision will be needed, consistently practiced, and widely advertised to solve this parking lot issue.

Most of these problems are beyond the focus of this paper, and beyond the TTIA group's control and the stakeholders control as well.

\subsection{When the Parking Lot is full of Parked Information Needs}

There is a lack of communication between all of the organizations. This disconnect has created these (real or perceived) parking lot information needs. Most of the information needs listed in section 8.10 show a lack of education and communication between organizations. Some recommended solutions might be: 
Education - Again people need to be aware of functions and funding topics. The Sandia phone book is one resource for this purpose. An electronic, searchable version of Sandia's Directory would be a start. Center Days, where each of the Center's sponsor a day to promote itself both internally and externally might also be an approach.

Location - Find the appropriate owner within the lab for better definition of functions. Is this a lab director project, a VP-level project? Might an outside contract be used to inventory Sandia functions and capabilities and look for overlaps? Same is true for the funding issue. It would seem rational for Corporate Strategic Planning, for instance, to create a matrix of alternative funding sources that the line organizations could use as a resource in the strategic planning that they do.

Parking lot issues that appear to be permanently "parked" include: location of additional pots of money for technology transfer agreements and project creation and merit reviews based on a technology transfer activity criteria.

\subsection{Further Actions That Might Be Taken}

Echoed throughout this section was the idea of proper location of the owner of the parking lot issues. Given that most of these topics are out of TTIA working group's hands, the best we can do is to raise these topics as issues and pass the information along. Locating the "proper" owner is a tough proposition in itself. Some simple steps to achieve this end include:

- Define of what the "functions \& funding" issues actually represent (perhaps by follow-up questionnaire to focus groups members and others as a reality check).

- Circulate the TTIA white paper to top management to get their input/suggested solutions.

- Continue to educate customers on the functions of the Technical Library and Technology Transfer thereby setting an example for other organizations to "advertise" their capabilities.

- Locate owners for issue that are too distant from the TTIA group and stakeholder purpose through surveying and or telephone calling. 


\subsection{FINAL RECOMMENDATIONS}

The conclusions of the TTIA working groups are based on the responses gained through primary research in the form of focus group sessions. More detailed justification for each of the recommendations can be found in the corresponding section of the paper.

\subsection{Marketing Information - Recommendations}

Since the marketing information needs were the most extensive and of the highest priority for the members of the focus groups, most of the recommendations in this section concern marketing information needs. The working group recommendations for marketing information include:

Design a Marketing Education Strategy - Both the Technical Library and Technology Transfer should combine resources and expertise to design a marketing seminar.

Communicate the Marketing Services - Create a campaign designed to emphasize the importance of Marketing at Sandia.

Work Together to Define a Snooth Process - Build on a good thing. Develop clear processes for internal market research and publicize it.

Build the library's collection of resources that supports technology transfer activities Select, purchase and make available journals, books, reports, and databases in tandem with Technology Transfer. Purchase of some of some new databases on CD-ROM is currently underway.

Assign a Technical Information Specialist to be a marketing information specialist The Technical Library decided to designate one Technical Information Specialist as a marketing information specialist in July 1994. Implementation of this plan is in progress.

\subsection{Technical Information - Recommendations}

Technical data is the "bread-and-butter" of Sandia's Technical Library. The Technical Library and the Technical Information Specialists do a good job of providing this type of information. Again the disconnect comes from a lack of awareness about the current products and services that the Technical Library offers. Education seems to be the key. In fact, the approach used for marketing information applies equally to the technical information. Therefore, the working group recommendations for technical information include: 
Design a Technical Information Education Strategy - The Technical Library has extensive resources and skills in the area of technical data. Many new products and services have, or are being reviewed and added to the Technical Library's menu. Educational workshops, classes, or seminars should be created to raise awareness and educate technical staff on the value of these products and services.

Communicate the Technical Information Services - Promotional activities such as wide announcement of the training workshops, articles in internal publications, a promotional brochure or one page flyer, etc. should be developed.

Build the library's collection of databases - Select, purchase, and make available databases that index the technical literature that will enable customers to do some of their own searching. Purchasing of several CD-ROM products that index the technical literature is also underway now.

\subsection{Delivery Issues - Recommendations}

The wants of information users in this area far outstrip the available resources and currently available communications technology at Sandia. As fiber optics come to every building, the transition to a "paperless" environment will gradually follow. Libraries nationwide will move towards electronic storage and retrieval of information, and use of print material will decrease.

In the interim, low technology solutions can be applied. For instance, a Technical Library staff member has been assigned to facilitate and improve the delivery process. This is a start at making improvements. The main recommendation for the delivery issues is the only one that the working groups members believe can be currently addressed:

Design a Process - Create a standard process with output metrics designed using the concepts of Total Quality Management. Seek internal assistance from Quality Tools, to audit, flowchart, evaluate, and the library delivery systems.

\subsection{Funding and Internal Information - Recommendations}

The funding information that is needed and the internal Sandia information that was desired are complex issues. For instance as total DOE funding is decreasing, funding for other government agencies is increasing. Who looks for additional and alternative sources of funding? The funding issue is a high-level activity beyond the control or focus of this group. However, the working group recommendation for funding information is:

Locate an owner of Funding Information - Currently, Technology Transfer is tracking some of the Federally funded programs. Could a funding working group be brought together across organizations with output from the group published on a regular basis? 
The same problem exists when trying to address internal Sandia information needs. As mentioned in the section above, the technology for a total integrated network is lacking. For instance, a lot of the desired information is already available on various databases scattered throughout the labs. No computer network brings all of these databases right to the desktop level. While there are privacy and security issues to be worked out, new technologies, such as client server architecture, should make sharing this information possible. The working group recommendation on internal information needs is:

Communicate Internal Information Needs to Architecture Project - The owner of this issue is outside of the focus of Technology Transfer or the Technical Library, although both organizations can certainly contribute information to this network once it is developed and implemented. A possible service that would meet this information need is a Sandia "yellow pages" of products and services offered by various department at the Laboratories. 
APPENDICES 
[THIS PAGE INTENTIONALLY LEFT BLANK.] 


\section{APPENDIX A: PROJECT CHARTER}

\section{Technology Transfer Information Audit Project Charter - May 1994}

\section{GOAL:}

(One sentence that defines specifically what will be accomplished and incorporates an event signifying completion.)

Evaluate existing information services that support Sandia Technology Transfer efforts and recommend improvements, new products and services.

\section{OBJECTIVES:}

(The Goal broken into pieces covering all aspects of the project.)

1) Identify customers

2) Determine methods that will be used to gather and evaluate customer input

3) Gather customer information requirements and expectations

4) Evaluate customer input and compare to existing system to reveal gaps

5) Identify improvements and new services

6) Make recommendations for implementation

7) Issue report

\section{SCOPE:}

(Limits: defines what will be included and what will not be included in the project.)

1) Management will resolve funding issues.

2) This project is limited to collecting, analyzing, prioritizing, summarizing, and communicating data.

3) The information from this project is meant to benefit all Sandia Technology Transfer activities.

\section{Restrictions:}

(Decisions already made and other important information that does not fit neatly into the above categories.)

1) This project will be completed by July 29, 1994.

2) External perceptions of the Technical Library and Technology Transfer Organization can bias customer input.

3) We all have competing priorities. 
[THIS PAGE INTENTIONALLY LEFT BLANK.] 
APPENDIX B: LIST OF FOCUS GROUP PARTICIPANTS AND LETTERS TO PARTICIPANTS

\author{
Technology Transfer Information Audit \\ List of Focus Group Participants
}

Tuesday, June 7, 1994

1221

Bob Turman

1273/4211 Terry Crow

1841

Bill Moffat

2665

Ned Godshall

2900

Patti Sanchez

4211

Mickey Harper

4211

Don Jones

4211

Joan Zaorski

6212

Merri Lewis

Wednesday, June 8, 1994

1434

Ed Marek

2401

Carla Chirigos

2800

4211

Brian Behling

4211

Deborah Belasich

4211

Matthew Bruff

4211

Jerry Hanks

4211

Toni Leon Kovarik

4211

4212

Walter Schimmel

Craig Sheward

4514

Glenn Baird

Sheryl Hingorani 


\section{Sandia National Laboratories}

P.O. Box 5800

Albuquerque, New Mexico 87185-0899
Managed and Operated by Sandia Corporation a subsidiary of Martin Marietta Corporation

May 31, 1994

\section{Dear Participant:}

Thank you for agreeing to participate in Technology Transfer Information Audit focus group on June 7 , 1994. The group will meet from 1:00 to 3:00 PM in the Building 10520 Conference Room. The Technology Transfer and Commercialization Center is located in this is this building. We will complete our discussions by 3:00 PM. Directions and more information on how to enter the building are on the accompanying page.

The goal of the Technology Transfer Information Audit project is to evaluate existing information services that support Sandia Technology Transfer efforts and recommend improvements, new products and services. Technology Transfer and the Technical Library are working together to ascertain the effectiveness of our current products and services in supporting Technology Transfer information needs, and determine what changes, including new products and services, need to be made. Technology Transfer is a new mission for the Laboratories and illustrates a turning point in Sandia's service to the nation.

We need your input in order to determine your information needs in relation to Technology Transfer. We know our customers have good ideas. We want you to use this forum to share with us your opinions on the types of products and services we need to offer to serve you better. We know that the right information at the right time will enhance your job performance.

During the focus groups the project team will be asking you:

- how you currently gather the information you need for Technology Transfer;

- what information needs are not being met, or not met as easily, quickly or effectively as they should be;

- what information you absolutely need in this area to do your job.

The project team will be preparing a report of their findings. This report will also include recommendations for new products and services, and plans for implementation. The team will provide the executive summary and/or the full report to each participant that requests a copy. The report will be finished sometime in August.

Again we thank you for agreeing to participate in this endeavor. If for any reason you find you cannot attend the focus group, please feel free to send an alternate that also has an interest in this topic. Please call a member of the project team if you cannot send an alternate, or if you have any questions or comments.

Project Team: Mary Compton (845-9268); Ken Cutshall (845-8246); Kathleen Manicke (271-7837); David Mays (845-9429)

Sincerely,

Olen Thompson,

Manager,

Technology Transfer Program Support
Sincerely,

Susan Stinchcomb, Manager, Technical Library Reference Department 


\section{Sandia National Laboratories}

P.O. Box 5800

Albuquerque, New Mexico 87185-0899
Managed and Operated by Sandia Corporation a subsidiary of Martin Marietta Corporation

June 22, 1994

Dear Participant:

Thank you for participating in our Technology Transfer Information Audit focus group on June 7 th. We hope you enjoyed the experience as much as we did. Your input will be invaluable to the project team as it proceeds with this project.

We knew our customers would have lots of good ideas and you did. The project team will prepare a report of their findings. They will also include recommendations for new products and services, and plans for implementation in this report. Each focus group participant who indicated they wanted a copy of the executive summary and/or the full report will receive a copy sometime in August.

Again we thank you for your participation. Please contact a member of the project team you have any questions, comments, or additional ideas.

Project Team:

Mary Compton, MS0899, (845-9268)

Ken Cutshall, MS0899, (845-8246)

Kathleen Manicke, MS1308 (271-7837)

David Mays, MS0899, (845-9429)

Sincerely,

Olen Thompson,

Manager,

Technology Transfer Program Support
Sincerely,

Susan Stinchcomb, Manager, Technical Library Reference Department 
[THIS PAGE INTENTIONALLY LEFT BLANK.] 
APPENDIX C: SPECIFIC FOCUS GROUP RESPONSES

\section{Technology Transfer Information Audit \\ Specific Focus Group Responses}

June 7 \& 8, 1994 
Tuesday

AGENDA

- Purpose a Intro 5 min

- Current State $20 \mathrm{~min}$

- Needs not Being Met $35 \mathrm{~min}$ a Possible Reasons

- Break

$10 \min$ - Essential Needs $35 \mathrm{~min}$
Assessment

- Summary a Wrap. up $15 \mathrm{~min}$ 
Tuesday

Ground Rules

- Everyone's Views Are Equal

- Not here to Discuss Merits of Programs

45 
Tuesday

Tech Transfer

$$
\text { Broker "Creating Bushes }
$$

BOTH WAYS Not Production"

Our TeCHNOLOGY $\rightarrow$

THEIR TECH

TO HELP SOLVE

SCIENCE $\rightarrow$ PARTNERSHIP

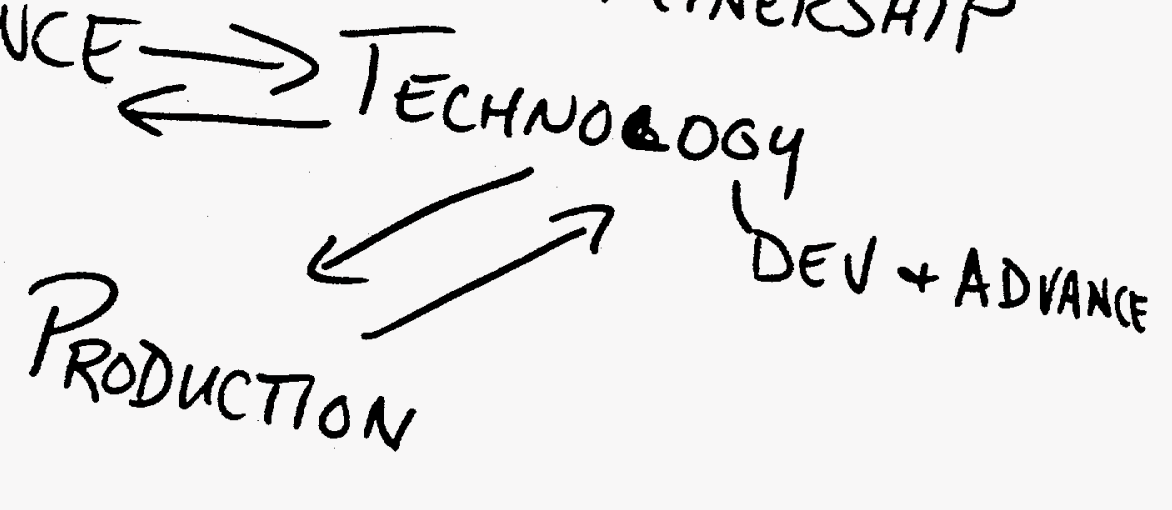

Currently Avail + Leading EDGE 


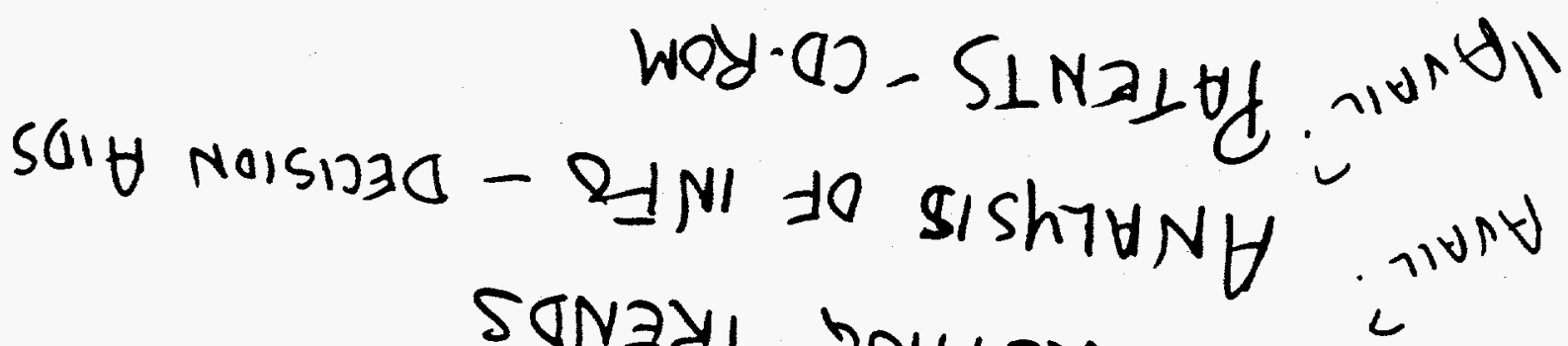

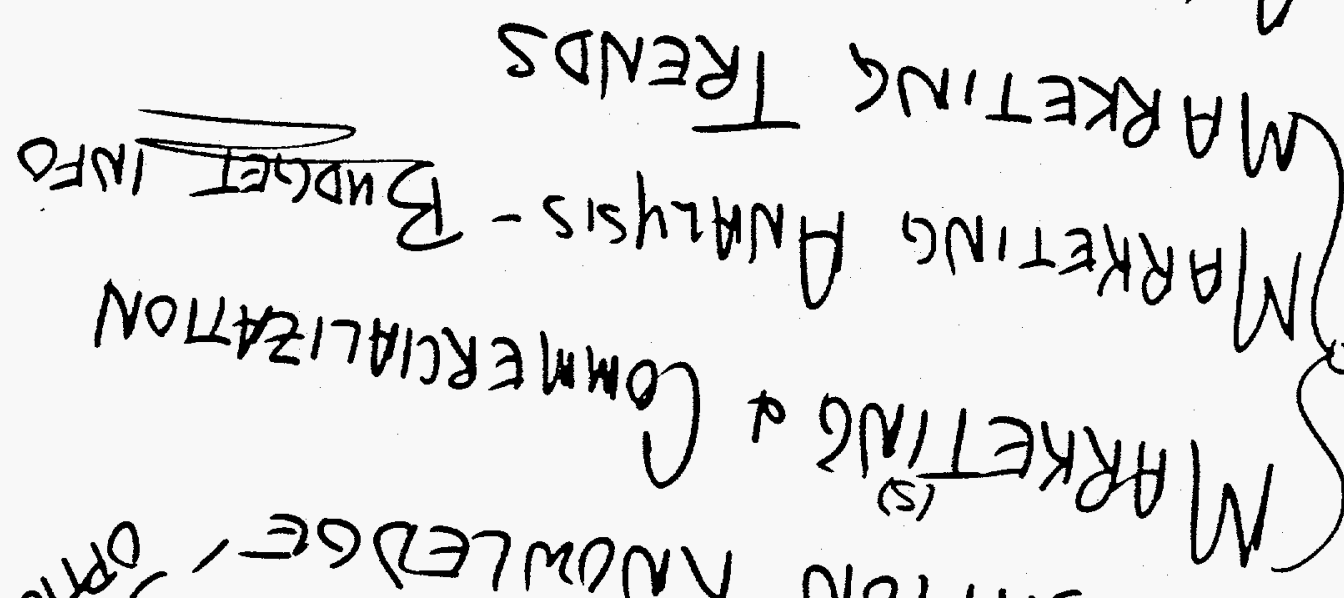

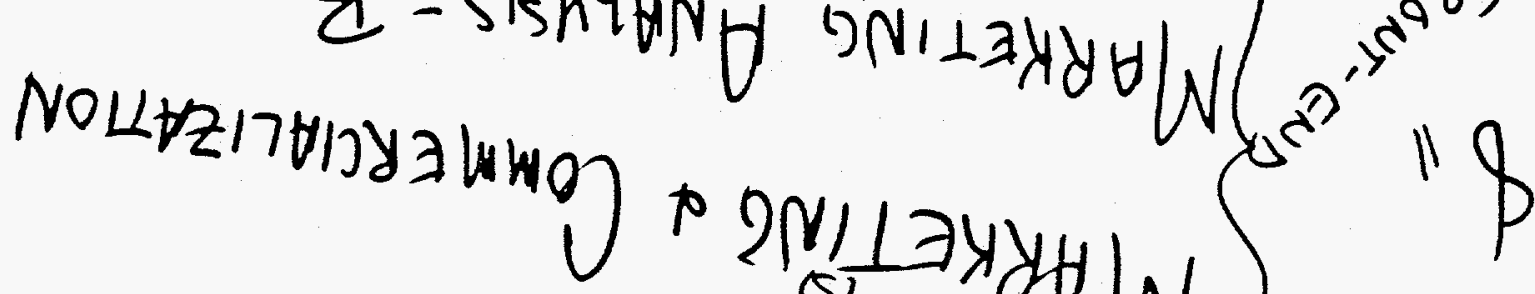
s.

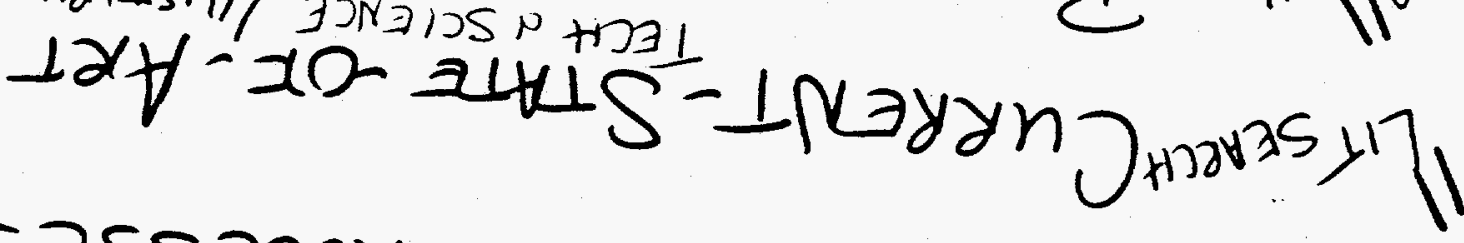

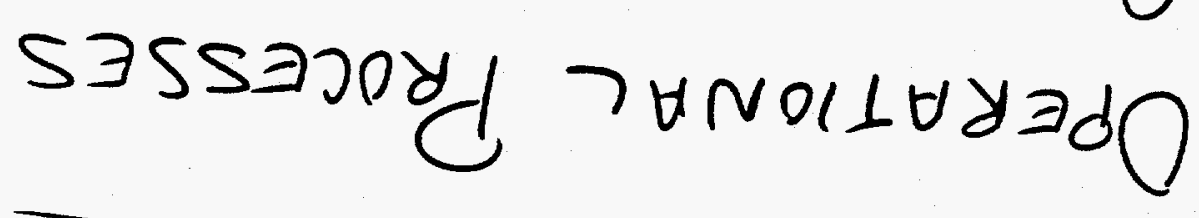


NEEDS

Tuesday

LUID- Funding Sources

curreser?

External a Internal

Lid - More Partnerships (S Nos I

- Other Projects (Teams) Not CENTRaLIZE) (DUP,

timely- For azan InFo 7 maybe Translated

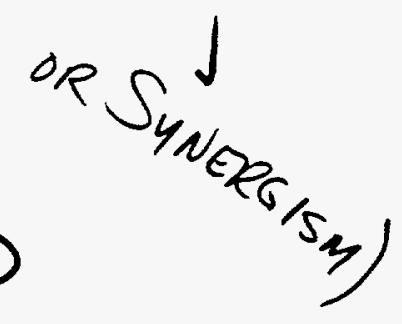

1 Mainstream info

- customer rocs /experts SOMETIMES ONE- STOP SHOPPING or DEFINED SERUICES

LATI - TRADE SHOW DATABANK

- Standard Language/ Format

SOON? -SkILLS DATABASE

48 
Tuesday ESSENTIAL NEEDS

- Marketing Needs

Producers/ Users

MARKET BARSTACES ID

"COMPetitor" Strengths

PARTNER d WEAKNeSSES

OF G COMPANESSES

MARKETS

IS THERE A NEED?

Market Profiles

StAGe or Development

TRENDS - WIDOWS OE OPPORTUNITY

PATENT

Rad is Sell

49 
Tues day

Directory OF SERVICES

BRochuRE FOR TECH TRANSFER

"Yellow Pages"

Kept Current

Electronic BuLlETIN BoARdS

Projects

CUSTOMERS

Trade SHOWS

EDUCATIONAL SERUICE

Patent Data $=\underset{\text { Doris }}{\text { Band }}$ D.

Bajkcine Service a Grades

50 
Tuesday

Issues

(SEED MONEY)

FUndING SOURCE FOR

Tech Transfer Activities

Charge Backs

WHO DOES IT?

DegreE a PrIORITIZATION 
NEEDS

(1)

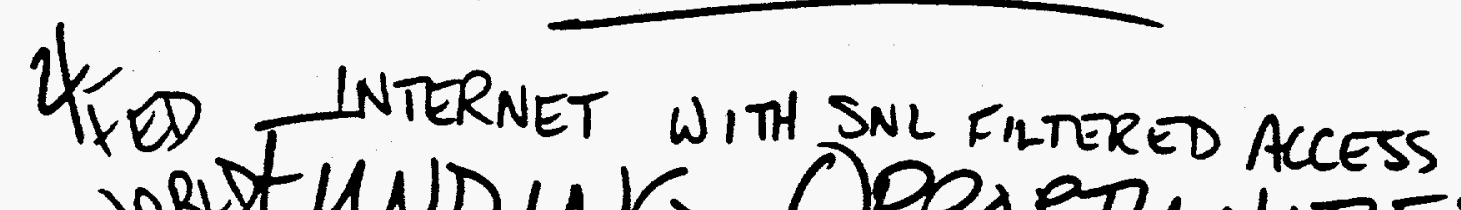

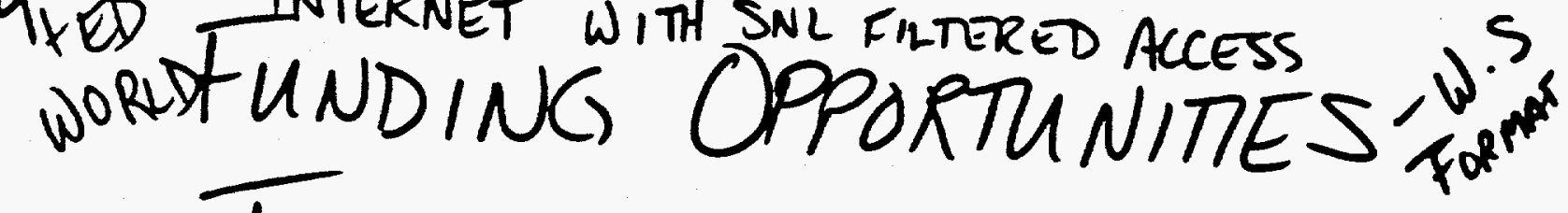

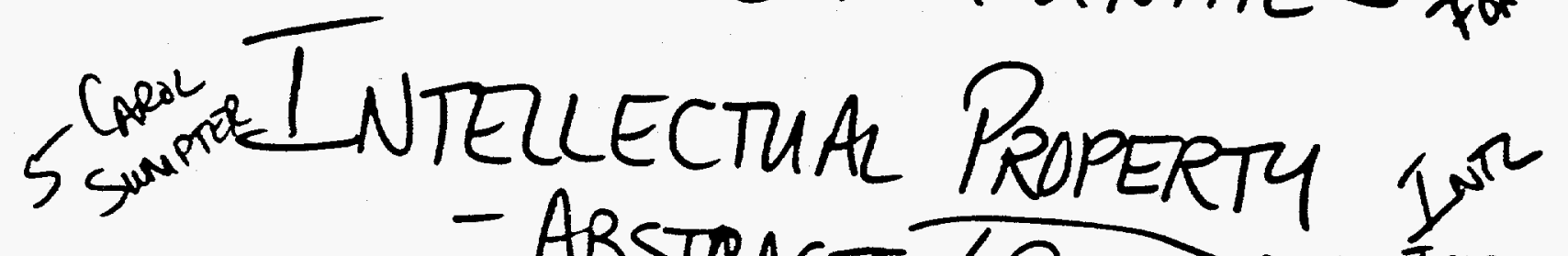

- ABSTRACTS/POC STD IMP

- INTERNAL 4 EXT.

Ww

patent Searches,

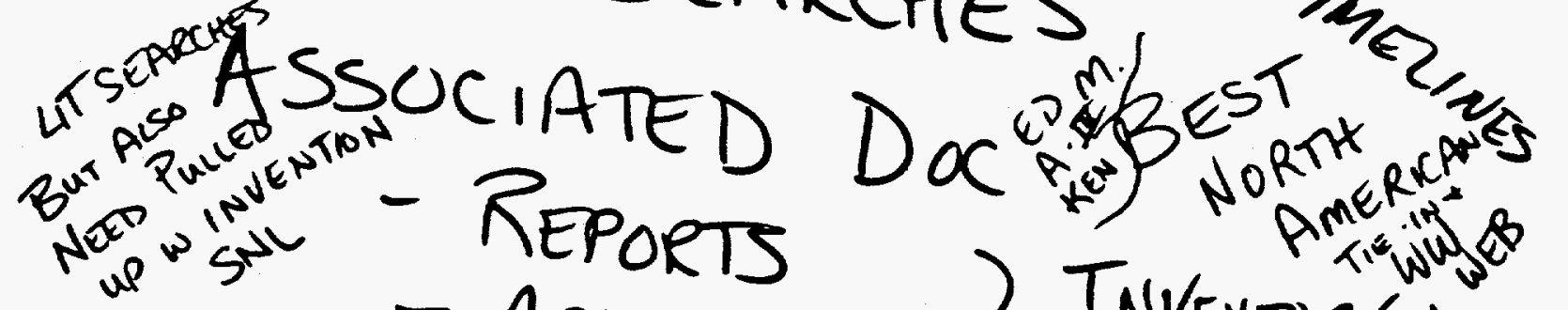

- Articles 3 INVENTOR (s)

Company Visitors To S SL

(Corporate Lever)

TECH TRENDS IN EC

52 
NEEDS

(2)

8 MARKETS FOR TWT POPP IN For DeGree of NEED $\downarrow$

8 PROPER VACUATION OE INT RoP Databases resrch

LIB Periodicals $\rightarrow$ LTt. Searech

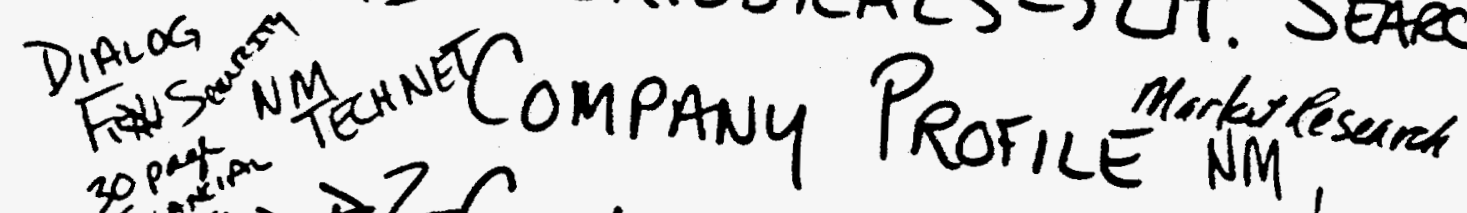

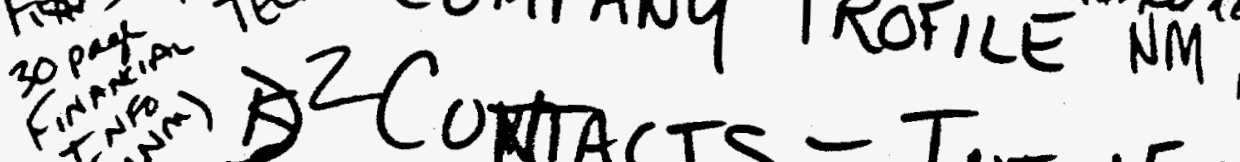
LNE ACTIVITES

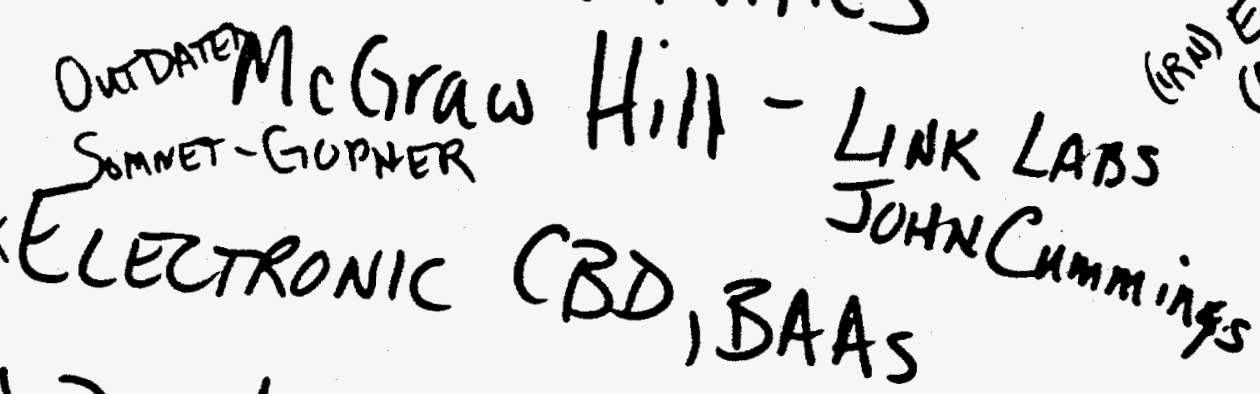
Kextus

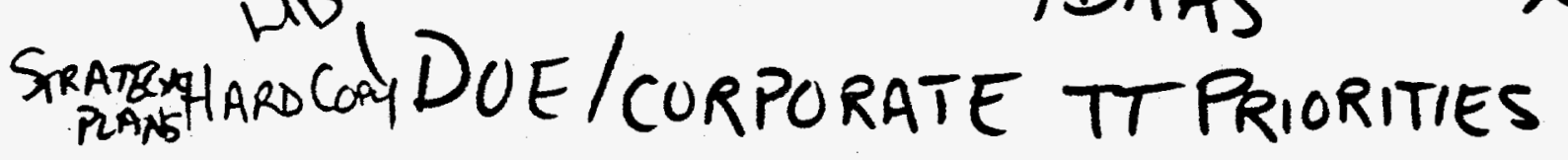

53 
NEEDS

(3)

Expositions SaL Pesentinsa

Posing Funding Trend, Customer Details

Pr Programs, Budgets

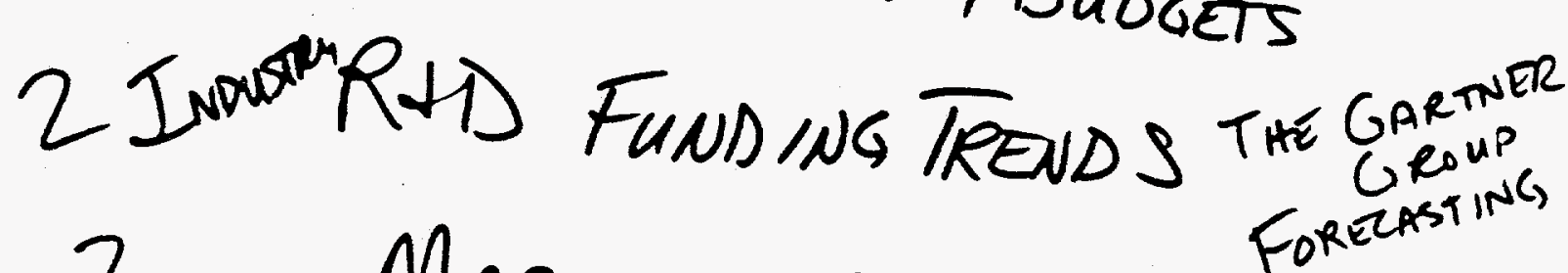

2 MARKET VIABILITY

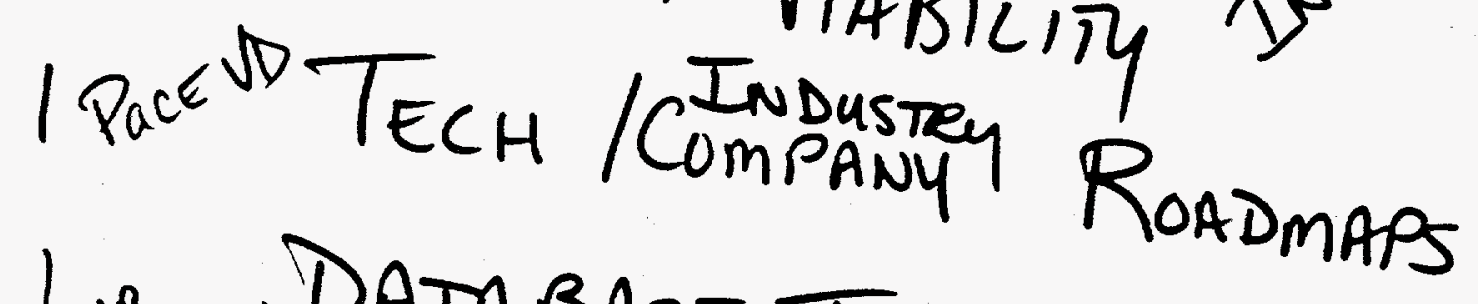

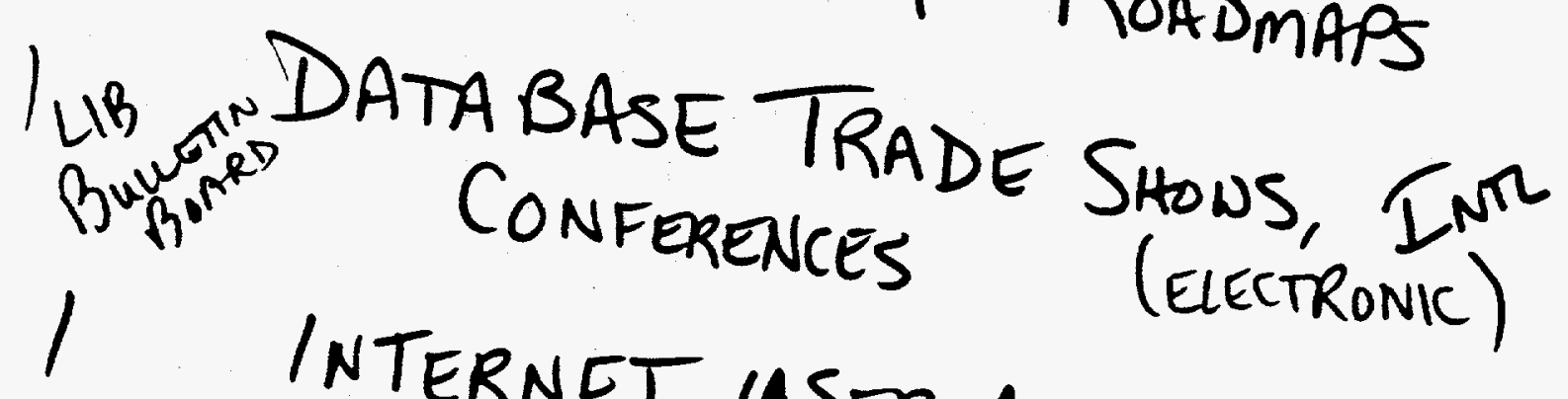

1 INTERNET USER AIDS (ww web)

dimula Corporate Annual wi ok Reports

INTR

54 
NEEDS

(4)

Dialos Moody's Manuks, ETr.

1 Business School materiazs ie unM SOURCES at SNL

Do Searches, Summarize SUNTIESIZE, ANALLSIS

LIST OF EXISTING SOURCES

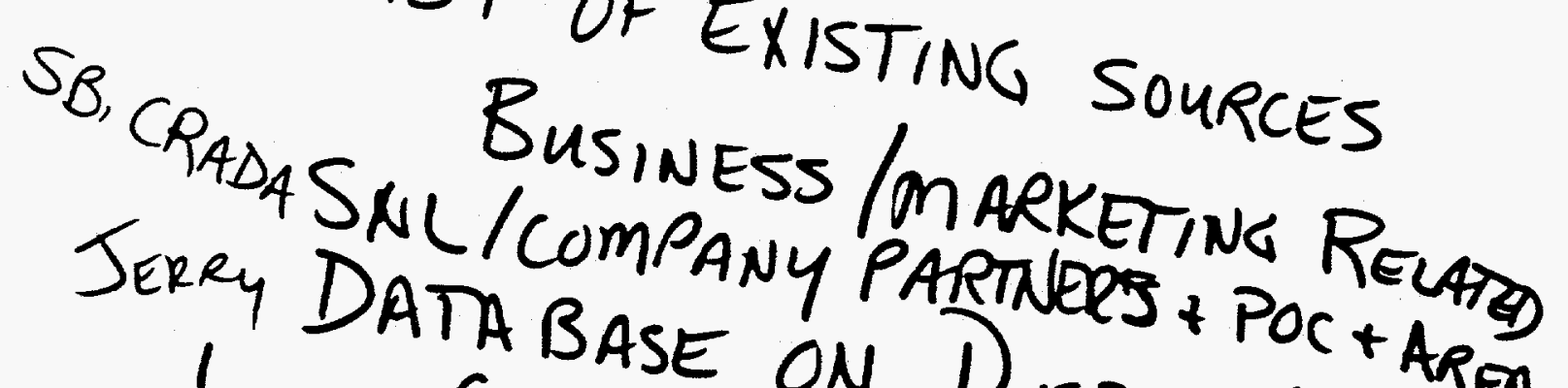

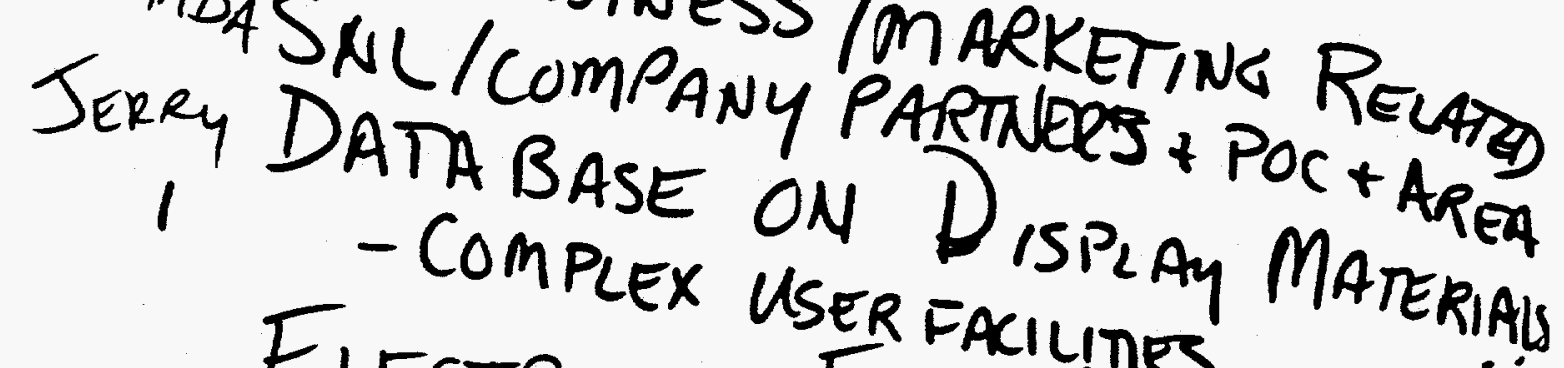

- COMPLEX USER FACILIMES

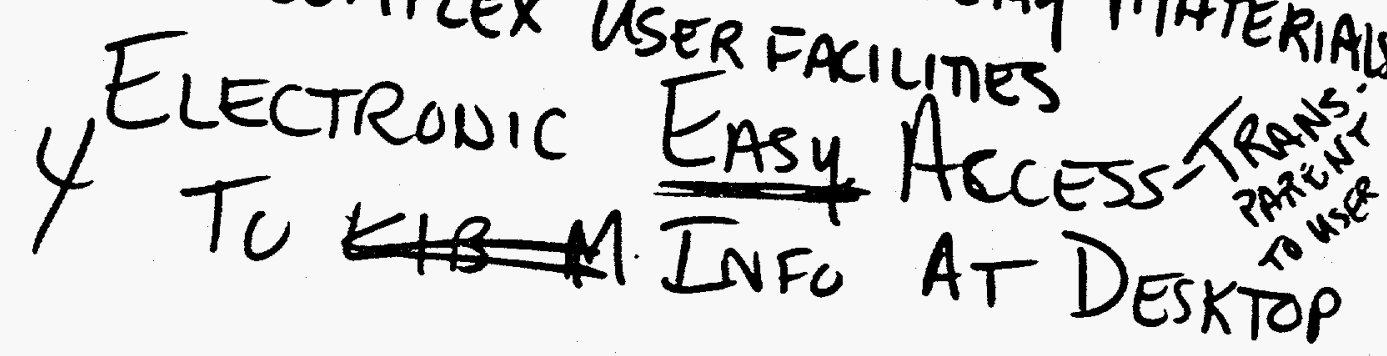

55 


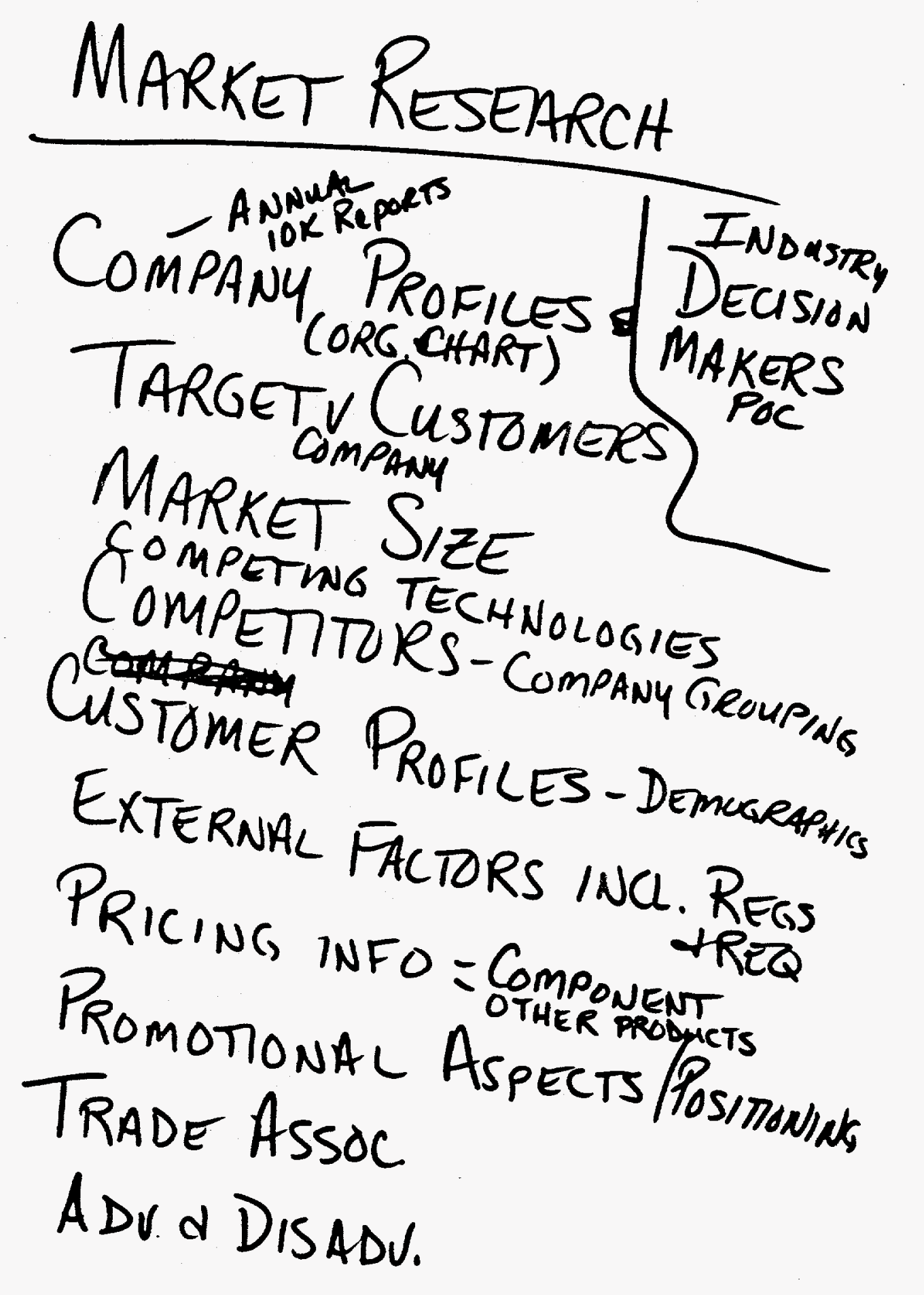


MARKET ID + VALUATIONS

- What are companies

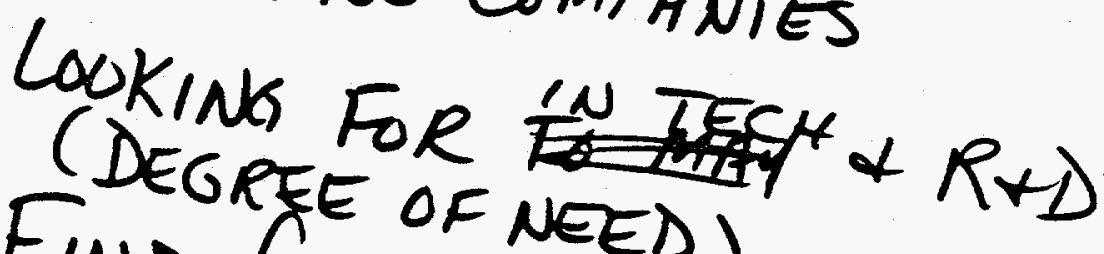
(DEGREE OF NEED)

- Find commercial markets

FOR SN TO LICENSE TO COMP

- Broad base market Analysis

- Unrelated markets (GRos saver)

- Proper valuation formic. Neo 
[THIS PAGE INTENTIONALLY LEFT BLANK.] 


\section{APPENDIX D: BODY LANGUAGE NOTES}

\section{Technology Transfer Information Audit}

\section{Body Language Notes}

Closed/Crossed Arms

Squinting Eyes

Resting Hand in chin

Leaning back, crossing arms and legs

Hand motions. Visually creating a box to frame his topic

Hand on face holding up head

Grooming hair

Nodding head

Chewing gum hard

Feet tapping, hand pounding on table

Lots of hand motions, exaggerated

Smiling, laughing

Pen clicking

Frowning, Brow wrinkling

Lip piercing, closing lips together tightly

Hands open

Counting point on fingers

Closed hands-calm

Big sighs

Head tilting

Playing with badges

Raising hands

Looking to others for agreement

Single hand outstretched against others, independent view-point expressed

Munching on pretzels

Flipping their pen

Bouncing back in their chair

Hand on top of head

Arm of head

Hands behind neck

Stretching

Legs spread apart, open

Shifting weight in chairs

Praying

Hands covering mouth, touching lips

Rubbing eyes, forehead 
[THIS PAGE INTENTIONALLY LEFT BLANK.] 


\section{APPENDIX E: SOURCES OFTEN USED FOR MARKETING INFORMATION}

\section{Sources Often Used for Marketing Information}

Books:

U.S. Industrial Outlook, annual, U.S. Department of Commerce.

Statistical Abstract of the United States, annual, U.S. Department of Commerce.

Encyclopedia of Business Information Sources, Eight edition, 1991-92, Gale.

Encyclopedia of Associations, annual, Gale.

Standard \& Poor's Register of Corporations, Directors and Executives, annual, Standard \& Poor's.

Online Sources:

At Sandia, online sources are more important than printed materials.

Directory information (company name, address, phone number, products, officials) is available in the various Dun \& Bradstreet files. The Thomas Register (both in print and online) is also useful.

Corporate Affiliations traces ownership relationships between companies.

More complete company information (balance sheet, history) is available in D\&B-Duns Financial Records Plus or Moody's Corporate Profiles. There is more information available for public companies than for private companies. It can be impossible to find anything on a small private company. Information on public companies can also be found in SEC records.

Access to the trade literature is provided by the Predicasts files.

PTS Annual Reports Abstracts

PTS F\&S Index

PTS New Product Announcements

PTS Prompt (Predicasts Overview of Markets and Technology)

PTS Newsletter Database

PTS Aerospace Markets \& Technology 
Trade \& Industry ASAP (Information Access) and full-test newspaper files are also useful.

Market and company information can be found in Investext.

Market reports can be found in the MARKETFULL files on Dialog; these files are very expensive. 
APPENDIX F: FLOW CHART OF MARKETING SERVICES AND MENU OF AVAILABLE PRODUCTS

\title{
FLOW CHART OF MARKETING SERVICES
}

\author{
AND
}

MENU OF AVAILABLE PRODUCTS 


\section{Do You Need Marketing Assistance?}

The Technology Transfer Center supports Product Engineers and Line Organizations in the areas of Marketing Research and Marketing Promotions. Our personnel can assist you in your full spectrum of marketing needs. Our process is simple and can include all, or just pieces, of the items listed. The process works like this:

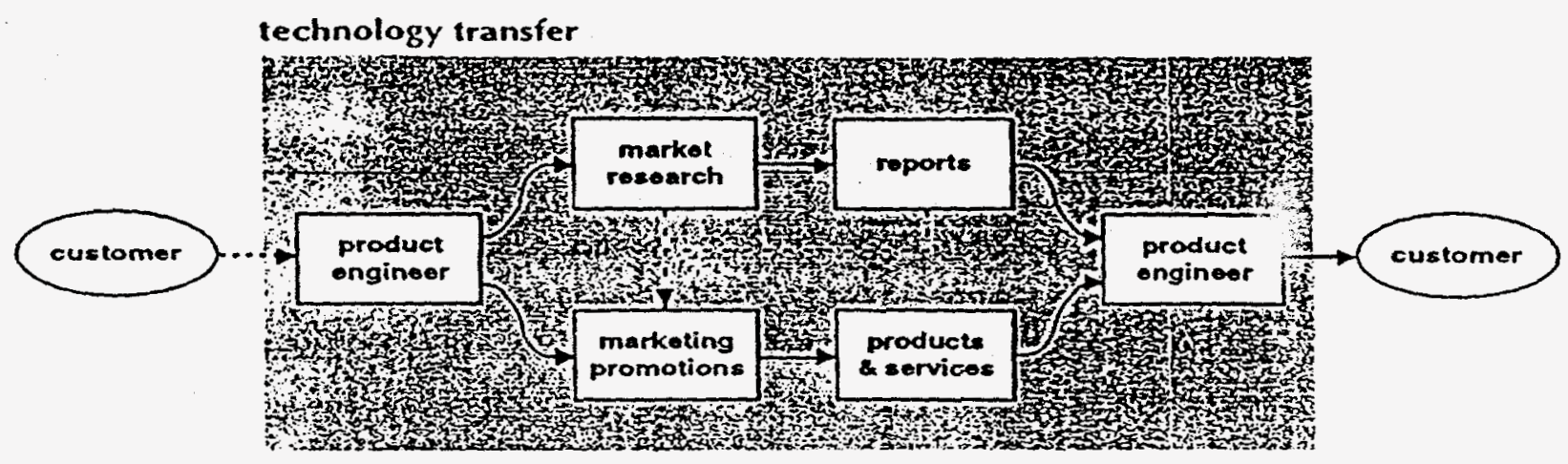

Marketing Research Capabilities:

External Environment

Industry Analysis

Company/Competition Profiles

Financial Details

Market Size

Technology Assessments

License Valuation

Marketing Planning

Survey Research

Marketing Strategies

Trade and Professional Associations

Industry Contaci List

Bibliography of Commercial Reports

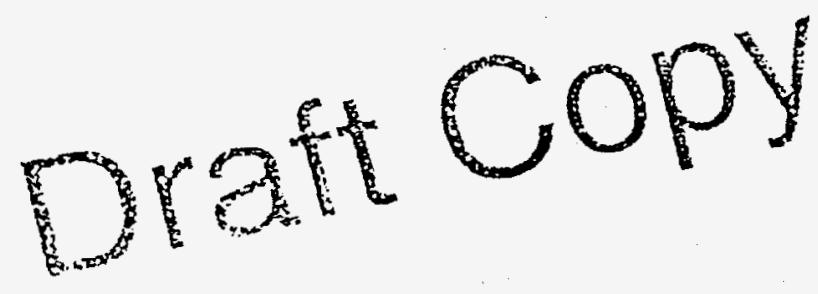

Marketing Promotion Capabilities:

Technology Fact Sheets

Brochures

Flyers

Displays

Exhibits

Trade Show Support

Contact Database and Reports

Partnership Development Advertising

\section{Who To Call:}

Marketing Research

Kathleen Manicke, 271-7837

Marketing Promotions

Mary Monson, 271-7831

Dru Popper-Lopez, 271-7852

Trade Show Coordination

Kay Carter, 271.7852 


\section{MARKET RESEARCH SPECIALIST MARKETING PROMOTIONS}

Kathleen Manicke

271-7837

- External Environment

- Industry Analysis

- Company/Competition Profile

- Financial Details

- Market Size/Forecasts -

Primary

Secondary

- Technology Assessments

- License Valuation

- Marketing Planning

- Survey Research

- Marketing Strategies

- Trade Show Matrix

- Trade/Professional Associations

- Industry Contacts List

- Bibliography Of Commercial Reports
Mary Monson

271-7831

- Trade Show Support

- Advertising - CBD Ads

- Direct Mailings

- Flyers

- Brochures

- Exhibit Design

- Technology Descriptions 
[THIS PAGE INTENTIONALLY LEFT BLANK.] 


\section{APPENDIX G：TYPES OF MARKETING STUDIES PROVIDED}

MP-Marketing Promotions: Study of marketing promotional avenues such as trade shows, trade publications, trade associations, technical journals, etc.

TV-Technical Valuation: Study of a specific technology which Sandia has developed, and the value of that technology in terms of market applications and market size.

IN-Industry Study: Study of the broad industry in which a Sandia technical capability exists including data from that industry.

IP-Intellectual Property Assessment: Study of a piece of Sandia intellectual property (usually patented), and its potential in the market, including potential partners.

BP-Business Partners: A list of potential users or developers of the Sandia technology, who may be interested in partnering with Sandia.

SV-Survey Research: Primary research of trade associations, businesses, or other industry experts on their opinions of the Sandia technology advantages and disadvantages.

PR-Purchased Report: An in-depth analysis conducted by a professional market research firm. Usually includes primary surveys of the private sector and contains more detailed information than is available internally through secondary sources.

RC: Summary of existing market research reports. 
[THIS PAGE INTENTIONALLY LEFT BLANK.] 


\section{Distribution:}

MS 0127 Sheryl L. Hingorani, 4514

0161 Carol W. Sumpter, 11510

0439 Edward L. Marek, 1434

0492 Heather W. Allen, 12323

0609 William C. Moffat, 1841

0612 Kathryn J. Olson, 13213

0630 L. Herb Pitts, 13400

0653 Sandra J. Barnes, 3522

0709 Merri R. Lewis, 6212

0782 Ruth A. Duggan, 5848

0898 R. Dennis Rowley, 13312

0898 P. Carol Jones, 13312

0899 Mary L Compton, 13415

0899 Kenneth J. Cutshall, 13415

0899 Sally A. Landenberger, 13414

0899 E. David Mays, 13415

0899 Elizabeth C. Moser, 13414

0899 Susan Stinchcomb, 13415

0953 Patrice M. Sanchez, 2900

0961 Carla D. Chirigos, 2401

1098 Jennie L. Negin, 13200

1182 Bob N. Turman, 1221

1194 James T. Crow, 1273

1359 Jeanne Evans, 12911

1380 Mark S. Allen, 4211

1380 Glenn Baird, 4212

1380 Deborah K. Belasich, 4211

1380 Matthew Bruff, 4211

1380 Jerry G. Hanks, 4211

1380 Michael Harper, 4211

1380 Donald E. Jones, 4211

1380 Toni Leon Kovarik, 4211

1380 Gordon T. Liefeste, 4211

1380 Cesar A. Lombana, 4211

1380 Kathleen A. Manicke, 4202

1380 Mary Monson, 4202

1380 Angelo Salamone, 4211

1380 Walter Schimmel, 4211

1380 Craig Sheward, 4211

1380 Olen D. Thompson, 4202

1380 John Walter, 4212

1380 Joan Zaorski, 4211

9211 Thespina Bernard, 8523 
1 MS 9018 Central Technical Files, 8523-2

50899 Technical Library, 13414

10619 Technical Publications, 13416

$10 \quad 0100$ Document Processing, 7613-2

for DOE/OSTI 